\title{
Cytological studies in some plants from cold deserts of India, Lahaul and Spiti (Himachal Pradesh)
}

\author{
Raghbir Chand Gupta, Himshikha, Puneet Kumar ${ }^{1}$ and Rajdeep Singh Dhaliwal
}

\author{
Department of Botany, Punjabi University, Patiala-147002, Punjab, India. \\ ${ }^{1}$ Author for correspondence (puneetbotcyto@gmail.com) \\ Received January 29, 2009; accepted April 19, 2009
}

\begin{abstract}
Detailed meiotic course and pollen fertility studies have been carried out in 23 species belonging to 14 families from the Indian cold deserts of Lahaul-Spiti. Out of these, new chromosome counts have been made in the three species, Chrysanthemum pyrethroides $(2 \mathrm{n}=3 \mathrm{x}=27,2 \mathrm{n}=4 \mathrm{x}=36)$, Waldhemia stoliczkai $(\mathrm{n}=9)$ and $W$. tomentosa $(\mathrm{n}=9)$. Meiotic course is abnormal in both the triploid and tetraploid cytotypes of $C$. pyrethroides which include univalents at metaphase, late disjunction of bivalents, formation of restitution nuclei at anaphase-I and chromatin bridges. Subsequently, microsporogenesis is also abnormal and is characterized by the occurrence of high frequency of monads, diads, triads, polyads, and micronuclei. These meiotic irregularities lead to high pollen sterility in both the cytotypes. Six species, Aquilegia fragrans $(\mathrm{n}=7)$, Astragalus bicuspis ( $\mathrm{n}=8)$, Cicer microphyllum $(\mathrm{n}=8)$, Bergenia stracheyi $(\mathrm{n}=17)$, Sedum ewersii $(\mathrm{n}=11)$, Datisca cannabina $(\mathrm{n}=11)$ and Silene vulgaris $(\mathrm{n}=12)$ are worked out chromosomally for the first time from India. An additional/varied intraspecific aneuploid cytotype has been recorded in Hypericum elodeoides $(n=9)$ against the earlier report of $2 n=16$ from other parts of India and elsewhere. The phenomenon of cytomixis involving inter PMC migration of chromatin material has been recorded in Anemone rivularis (n=8), Caltha palustris $(\mathrm{n}=16)$, Meconopsis aculeata $(\mathrm{n}=28)$ and Potentilla fruticosa var. rigida $(\mathrm{n}=7)$. Cytomixis in Anemone rivularis $(\mathrm{n}=8)$ and Caltha palustris $(\mathrm{n}=16)$ resulted into high percentage of pollen malformation and heterogenous sized fertile pollen grains. In the remaining species, the meiosis is perfectly normal leading to very high pollen fertility. Our counts for rest of the species substantiate the previous chromosome reports by other workers.
\end{abstract}

KEYWORDS: Chromosome number, Chrysanthemum pyrethroides, Cytomixis, Meiotic irregularities, Waldhemia stoliczkai, W. tomentosa

Lahaul-Spiti, a cold desert in the north-west Himalaya and the largest district of Himachal Pradesh with an area of ca.12, $210 \mathrm{~km}^{2}$, comprises two sub-divisions as LahaulSpiti. Kunzum Pass $(4,550 \mathrm{~m})$ keeps these two subdivisions isolated from each other for more than six months due to heavy snowfall. The area is more desolate and barrenness is the rule here. Climate of Lahaul - Spiti varies considerably. Rainfall in the area is very scanty. Snowfall occurs in winter. August is the hottest month with temperature rising up to $30^{\circ} \mathrm{C}$ during day time, while January is the coldest when mercury dips up to $-30^{\circ} \mathrm{C}$ or below. Except the periods of rain or snowfall, the air is very dry in both the summer and winter, and strong winds blow almost throughout the year. Consequently, the plants tend to become prostrate, thick, bushy, hardy, and spiny with long roots and small succulent or woolly leaves. Majority of the plants are perennials and survive through underground parts. Due to geographical isolation and specific ecological conditions, the flora of the area shows plenty of endemics. Further, consequent to harsh climate conditions and high incidence of UV rays the plants of the area expected to show a considerable amount of genetic diversity in the form of intraspecific polyploidy, aneuploidy, hybridization, apomixis, and associated meiotic irregularities.

The flora of Lahaul- Spiti has attracted the attention of number of botanists over the years. But all these studies pertain to floristic diversity and ethnobotanical surveys. Except for some chromosome reports (Bhatia 2005, Pimenov et al. 2006, Kumar and Singhal 2008, Singhal and Kumar 2008), no systematic attempt has so far been made to explore the existence of cytomorphological diversity, meiotic behaviour, and pollen fertility of the plants of the region. The purpose of the present studies is to record the original chromosome counts and to study the meiotic behaviour and pollen fertility.

\section{Materials and Methods}

Materials for cytological studies were collected from Lahaul-Spiti and adjoining high hill areas during the months of May-September during the year 2007 when the area is open for traffic. The voucher specimens of the worked out species are deposited in the Herbarium, Department of Botany, Punjabi University, Patiala (PUN). For meiotic chromosome counts, floral buds of appropriate sizes were fixed in Carnoy's fixative for $24 \mathrm{~h}$ and then preserved in $90 \%$ alcohol at $4{ }^{\circ} \mathrm{C}$ in the refrigerator. Smears of pollen mother cells were made in $1 \%$ acetocarmine. Meiotic preparations were made permanent after grading through a mixture of acetic acid and alcohol and then through absolute alcohol before mounting in euparal. A number of freshly prepared and permanent slides were examined to determine the chromosome number at different stages and meiotic abnormalities. To estimate the pollen fertility mature anthers were smeared in glycerol-acetocarmine mixture (1:1). Well filled pollen grains with stained nuclei were taken to be apparently fertile while those with shrivelled up nuclei and unstained cytoplasm as sterile. Photomicrographs of chromosome counts and pollen grains were 
made from the freshly prepared slides using Leica Qwin Digital Imaging System.

\section{Results And Discussion}

The present work included detailed meiotic course and pollen grains studies on 23 species belonging to 14 families. Information on meiotic chromosome numbers, sources of materials, plant accession numbers, ploidy level and \% age pollen fertility were provided in the Table 1 . The new or varied chromosome counts were based on data collected from Darlington and Wylie (1955), Fedorov (1969), Moore (1973, 1974, 1977), Löve and Löve (1982), Goldblatt (1975-1978, 1979-1981, 1982-1983, 1984-1985), Goldblatt and Johnson (19861987, 1988-1989, 1990-1991, 1992-1993, 1994-1995, 1996-1997, 1998-2000, 2001-2003 ) and Kumar and Subramanian (1986). Only species with result of cytological interest are dealt herewith.

1. Anemone rivularis Buch.- Ham. ex DC. Locally referred as 'Chutrak', is a perennial herb with whitish, bluish or purplish flowers, found in bushes in the forests and open slopes. The species is commonly distributed between 2,000 - 3,500 m altitudes in the Himalayas. The meiotic chromosome count of $n=8$ is confirmed from the presence of 8-large sized bivalents with terminal and interstitial chiasma at Metaphase I (MI) (Fig. 1). The phenomenon of cytomixis, involving transfer of chromatin material is recorded in proximate PMCs (Fig. 2). Consequent to cytomixis, the PMCs with extra chromatin material were also observed (Fig. 3). The impact of cytomixis in the presently studied individuals from Gulaba results into high pollen sterility (40\%) and variable sized pollen grains (Fig. 4).

2. Caltha palustris L. Also known as 'Kingcup' or 'Marsh Marigold' was distributed in the temperate regions of Western Himalayas between 2,600 m to 3,300 $\mathrm{m}$, prefers to grow along the streams, wet places such as marshes, ditches and glacial moraines. Two populations from different areas (Kukumsheri 2,869 m; Kishori 3,000 $\mathrm{m})$ have been included for meiotic studies. These populations which existed at tetraploid level uniformly show the presence of 16 bivalents at MI (Fig. 5). Majority of the individuals in one of the population from Kishori showed normal meiotic course and $100 \%$ pollen fertility. However, the individuals in the population from Kukumsheri area showed inter PMC transfer of chromatin material at various stages of meiosis (Fig. 6). The phenomenon of cytomixis in these individuals resulted into various meiotic irregularities such as chromosome stickiness (Fig.7), pycnotic chromatin (Fig. 8) and micronuclei in tetrads (Fig. 9) .The phenomenon of cytomixis which did not affect apparent pollen fertility resulted in the formation of heterogenous sized fertile pollen grains (Fig. 10). The same tetraploid chromosome number and the phenomenon of cytomixis have also been reported in other Himalayan populations from this laboratory (Kumar and Singhal 2008). The Indian population from Kashmir Himalayas earlier known to have tetraploid, 2n=32 (Malik and Mary 1970) and hexaploid, 2n=48 cytotypes (Kurosawa 1971, Roy and Sharma 1971). Malik and Mary (1970) have also reported the presence of up to $4 \mathrm{~B}$-chromosomes in the individuals of these populations. The chromosome record of $2 n=40$ by Mehra and Remanandan (1972) needed confirmation because Kurosawa (1971) reported earlier from the same locality the existence of a hexaploid cytotype with $2 n=48$. The species has been worked out quite extensively from several other regions of the world which included Russia, Europe, North America, Arctic region and Asia, and was reported to exhibits an array of chromosome numbers such as $2 \mathrm{n}=16,28,32,35,44,48$, $52,54,55,56,57,58,60,64,68,70,72,88$ depicting a reticulum of polyploid derivatives. It was, thus, apparent that the species was in active state of evolution involving aneuploidy, polyploidy and hybridization. Further, the heterogeneity in chromosome number in the species could also be attributed to the presence of cytomixis and variable number of B-chromosomes in some populations.

3. Meconopsis aculeata Royle The species which was referred as 'Himalayan blue poppy' grew as an erect and prickly perennial herb in rocks and on stony slopes. The beautiful bluish colored flowers appear during May-July. The species which was endemic to East Asia has been included in IUCN list of threatened species in the high hills of Jammu and Kashmir, Himachal Pradesh and Uttar Pradesh. The tetraploid count of $n=28$ in the presently studied individuals has been confirmed from the presence of 28 large sized bivalents in PMCs at MI (Fig. 11). These individuals also showed transfer of chromatin material in few PMC during meiosis (Fig. 12). As a consequence of cytomixis various other associated meiotic abnormalities such as chromosome stickiness (Fig. 13), laggards and bridges during anaphases and telophases were resulted (Figs. 14 and 15). The same tetraploid chromosome number and the phenomenon of cytomixis have also been reported in other Himalayan populations from this laboratory (Singhal and Kumar 2008). The present count of $n=28$ was in agreement with the earlier reports of $2 n=56$ (Ratter 1968, Jee et al. 1989). The species was already known to have a diploid cytotype 2 n=28 (Sugiura 1937) from outside India which indicated towards the existence of intraspecific polyploidy $(2 \mathrm{x}, 4 \mathrm{x})$.

4. Hypericum elodeoides Choisy Locally referred as 'basanti', grew as perennial herb with sessile leaves and yellow coloured flowers. It grows in damp meadows between 1,600-3,500 $\mathrm{m}$ in the Himalayas. During meiosis, nine small sized bivalents were clearly discernible at diakinesis and MI (Fig. 13). Further, meiotic course and 
Table 1. Data on locality with altitude, accession number, meiotic chromosome number, ploidy level and pollen fertility $(\%)$ of the presently studied species.

\begin{tabular}{|c|c|c|c|c|c|c|}
\hline Taxon & $\begin{array}{l}\text { Locality with altitude } \\
\text { in meters }\end{array}$ & $\begin{array}{l}\text { AN } \\
(\text { PUN) }\end{array}$ & $\begin{array}{c}\mathrm{MCN} \\
(\mathrm{n})\end{array}$ & PL & $\begin{array}{l}\mathrm{PF} \\
(\%)\end{array}$ & Remarks \\
\hline \multicolumn{7}{|l|}{ Family: Ranunculaceae } \\
\hline $\begin{array}{l}\text { 1. Anemone rivularis Buch. } \\
\text { - Ham. ex DC. }\end{array}$ & Gulaba 3,200 & 49393 & 8 & $2 \mathrm{x}$ & 60 & $\begin{array}{l}\text { Inter PMC chromatin transfer results in } \\
\text { pollen sterility and pollen grains of } \\
\text { variable sizes. }\end{array}$ \\
\hline 2. Aquilegia fragrans Benth. & Gramphu 3,300 & 49392 & 7 & $2 \mathrm{x}$ & 86 & Meiosis normal. \\
\hline \multirow[t]{2}{*}{ 3. Caltha palustris $\mathrm{L}$. } & Kukumsheri 2,869 & 49367 & 16 & $4 \mathrm{x}$ & 98 & $\begin{array}{l}\text { Cytomixis results into heterogenous sized } \\
\text { pollen grains. }\end{array}$ \\
\hline & Kishori 3,000 & 49370 & 16 & $4 \mathrm{x}$ & 100 & Normal meiosis. \\
\hline \multicolumn{7}{|l|}{ Family: Papaveraceae } \\
\hline 4. Meconopsis aculeata Royle & Marhi 3,400 & 49389 & 28 & $4 \mathrm{x}$ & 100 & $\begin{array}{l}\text { Cytomixis results into meiotic } \\
\text { irregularities. }\end{array}$ \\
\hline \multicolumn{7}{|l|}{ Family: Brassicaceae } \\
\hline $\begin{array}{l}\text { 5. Nasturtium officinale } \mathrm{R} . \mathrm{Br} \text {. } \\
\text { Family: Caryophyllaceae }\end{array}$ & Tandi 2,573 & 49386 & 16 & $4 \mathrm{x}$ & 100 & Normal meiosis. \\
\hline \multicolumn{7}{|l|}{ Family: Hypericaceae } \\
\hline 7. Hypericum elodeoides Choisy & Gulaba 3,000 & 49391 & 9 & $2 \mathrm{x}$ & 100 & $\begin{array}{l}\text { Report of new aneuploid cytotype. } \\
\text { Normal meiosis. }\end{array}$ \\
\hline \multicolumn{7}{|l|}{ Family: Linaceae } \\
\hline $\begin{array}{l}\text { 8. Linum perenne } \mathrm{L} \text {. } \\
\text { Family: Fabaceae }\end{array}$ & Mud 3,500 & 49387 & 18 & $4 \mathrm{x}$ & 100 & Normal meiosis. \\
\hline 9. Astragalus bicuspis Fisch. & Gondhla 3,160 & 49388 & 8 & $2 \mathrm{x}$ & 62 & \multirow{2}{*}{$\begin{array}{l}\text { First report from India. Inter PMC } \\
\text { chromatin transfer results into pollen } \\
\text { sterility and pollen grains of variable } \\
\text { sizes. }\end{array}$} \\
\hline \multirow[t]{2}{*}{ 10. A. munroi Benth. } & Zingzingbar 4,000 & 49395 & 8 & $2 \mathrm{x}$ & 100 & \\
\hline & Tindi 2,740 & & 8 & $2 \mathrm{x}$ & 30 & Normal meiosis. \\
\hline \multicolumn{7}{|l|}{ Family: Rosaceae } \\
\hline $\begin{array}{l}\text { 12. Potentilla fruticosa L.var. rigida } \\
\text { (Wall. ex Lehm.) Th. Wolf }\end{array}$ & Marhi 3,400 & 49399 & 7 & $2 \mathrm{x}$ & 80 & $\begin{array}{l}\text { New cytotype. Cytomixis results into } \\
\text { some pollen malformation. }\end{array}$ \\
\hline 13. Rosa webbiana Wall. ex Royle & Keylong 3,340 & 49401 & 7 & $2 \mathrm{x}$ & 100 & Normal meiosis. \\
\hline $\begin{array}{l}\text { 14. Spiraea sorbifolia } \text { L. Family: } \\
\text { Saxifragaceae }\end{array}$ & Udaipur 2,743 & 49494 & 9 & $2 \mathrm{x}$ & 100 & Normal meiosis. \\
\hline $\begin{array}{l}\text { 15. Bergenia stracheyi } \\
\text { (Hook. f. \& Thoms.) Engler }\end{array}$ & Gramphu 3,300 & 49227 & 17 & $2 \mathrm{x}$ & 70 & First report from India. Meiosis normal. \\
\hline \multicolumn{7}{|l|}{ Family: Crassulaceae } \\
\hline \multicolumn{7}{|l|}{ Family: Datiscaceae } \\
\hline $\begin{array}{l}\text { 17. Datisca cannabina } \mathrm{L} \text {. } \\
\text { Family: Asteraceae }\end{array}$ & \multicolumn{4}{|c|}{ Family: Asteraceae } & 100 & First report from India. Meiosis normal. \\
\hline \multirow[t]{2}{*}{$\begin{array}{l}\text { 18. Chrysanthemum pyrethroides } \\
\text { (Kar. \& Kir.) Fedtsch. }\end{array}$} & Batal 3,960 & 49405 & $2 n=27$ & $3 \mathrm{x}$ & 26 & $\begin{array}{l}\text { First ever report for the species. } \\
\text { Abnormal meiotic course and } \\
\text { microsporogensis. }\end{array}$ \\
\hline & Batal 3,960 & 49385 & $2 n=36$ & $4 \mathrm{x}$ & 60 & $\begin{array}{l}\text { First ever report for the species. } \\
\text { Abnormal meiotic course and } \\
\text { microsporogensis. }\end{array}$ \\
\hline 19. Lactuca dissecta D. Don & Keylong 3,340 & 49384 & 8 & $2 \mathrm{x}$ & 100 & Normal meiosis. \\
\hline $\begin{array}{l}\text { 20. Waldhemia stoliczkai }(\mathrm{Cl} .) \\
\text { Osten. f. }\end{array}$ & Batal 3,960 & 49404 & 9 & $2 \mathrm{x}$ & 100 & $\begin{array}{l}\text { First ever report for the species. Normal } \\
\text { meiosis. }\end{array}$ \\
\hline 21. W. tomentosa (Decne) Regel & Batal 3,960 & 49403 & 9 & $2 \mathrm{x}$ & 100 & $\begin{array}{l}\text { First ever report for the species. Normal } \\
\text { meiosis. }\end{array}$ \\
\hline \multicolumn{7}{|l|}{ Family: Solanaceae } \\
\hline \multicolumn{6}{|l|}{ Family: Phytolaccaceae } & Normal meiosis. \\
\hline 23. Phytolacca acinosa Roxb. & Gulaba 3,000 & 49402 & 36 & $8 \mathrm{x}$ & 100 & Normal meiosis. \\
\hline
\end{tabular}

$\mathrm{AN}=$ Accession number; $\mathrm{MCN}=$ Meiotic chromosome number; $\mathrm{PL}=$ Ploidy level; $\mathrm{PF}=$ Pollen fertility. 


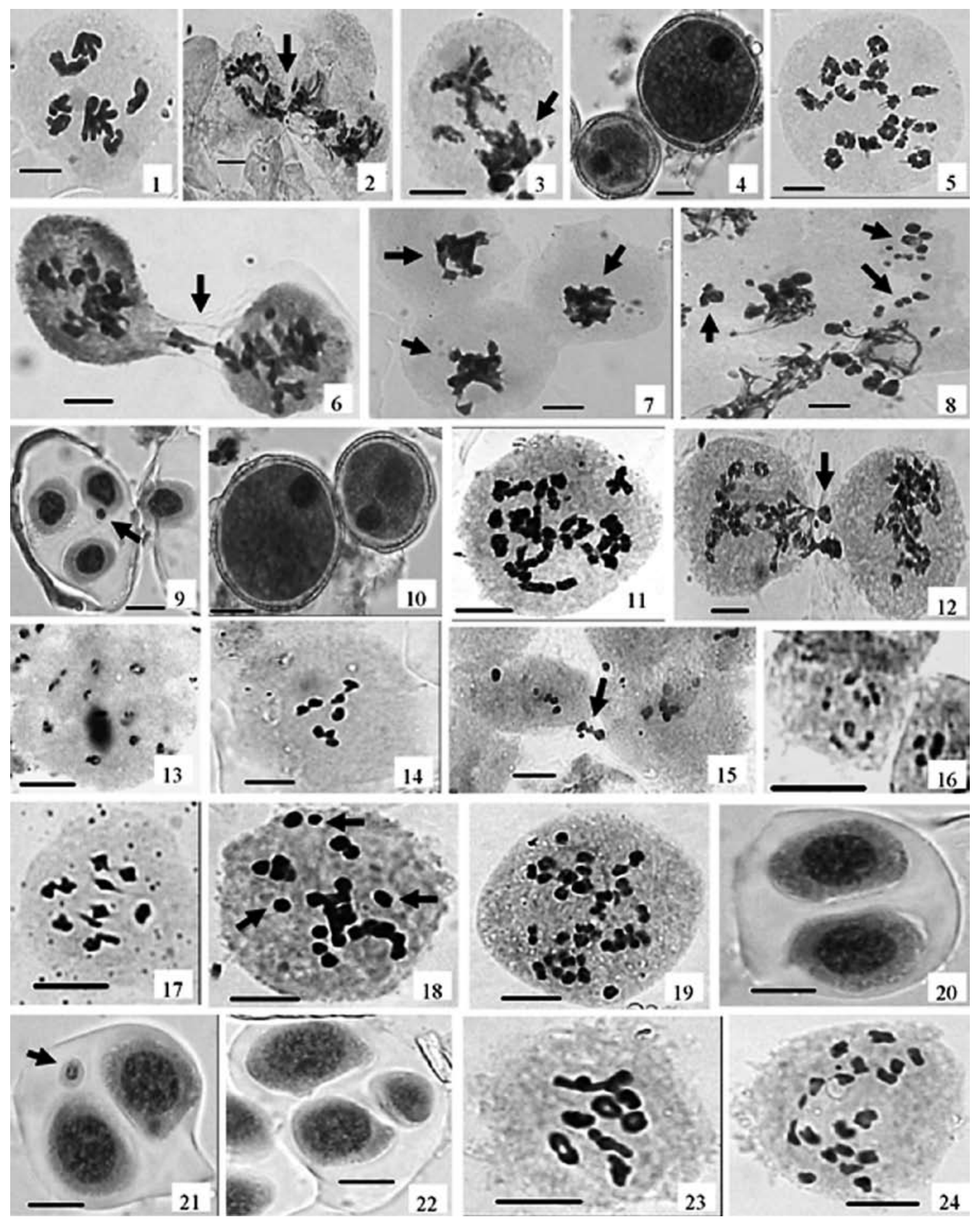

Fig. 1. Chromosomes of some plants in cold deserts of India, Lahaul and Spiti. 1-4. Anemone rivularis Buch.-Ham. ex DC. 1. A PMC showing large sized $8_{\text {II }}$ at diakinesis. 2. Two PMCs showing transfer of chromatin material (arrowed). 3. A PMC showing extra chromatin material (arrowed). 4. Unequal sized fertile pollen grains. 5-10. Caltha palustris L. 5. A PMC showing $16_{\text {II }}$ at metaphase -I (MI). 6. Two PMCs showing transfer of chromatin and thread like stretched cytomictic channels (arrowed). 7. PMCs showing chromatin stickiness (arrowed). 8. PMCs with pycnotic chromatin scattered in cytoplasm (arrowed). 9. A tetrad with one micronucleus (arrowed). 10. Fertile unequal sized pollen grains. 11-and 12. Meconopsis aculeata Royle 11. A PMC showing 28 $8_{\text {II }}$ at MI. 12. Two PMCs involved in transfer of chromatin (arrowed). 13. Hypericum elodeoides Choisy. A PMC showing $9_{\text {II }}$ at diakinesis. 14 and 15. Astragalus bicuspis Fisch. 14. A PMC showing $8_{\text {II }}$ at MI. 15. Two PMCs showing transfer of chromatin (arrowed). 16. Potentilla fruticosa L. var. rigida (Wall. ex Lehm.) Th. Wolf A PMC showing $7_{\text {II }}$ at MI. 17. Sedum ewersii Led. A PMC showing $11_{\text {II }}$ at MI. 18-22. Chrysanthemum pyrethroides (Kar. et Kir.) Fedtsch. 18. A PMC of triploid cytotype with $2 \mathrm{n}=27$ showing univalents (arrowed) and bivalents at MI. 19. A PMC of tetraploid cytotype with18: 18 chromosome distributions at AI. 20. A diad. 21. A triad with unequal sized microspores. 22. A diad with micronucleus (arrowed). 23. Waldhemia stoliczkai (Cl.) Osten.f. A PMC at MI showing 9 bivalents. 24. W. tomentosa (Decne) Regel A PMC with 9: 9 chromosome distributions at AI. 
microsporogenesis was normal resulting into 100\% pollen fertility. The present chromosome report added a new aneuploid cytotype to the already existing report of $2 n=16$ from Shimla hills (Sandhu and Mann 1989) and outside India (Sugiura 1941, 1944).

5. Astragalus bicuspis Fisch. A xeromorphic deciduous hardy and thorny shrub was widely distributed in Tibet, Qinghai, Pakistan and certain high altitude areas of Kashmir, Sikkim and Himachal Pradesh. The species was highly valuable for soil and water conservation in high hill areas. It provides highly nutritious protein feed for cattles. Presently two populations were included for meiotic studies and both unequivocally showed eight equal sized bivalents at MI (Fig. 14). This was the first chromosome count from India but was in line with the earlier records of $2 \mathrm{n}=16$ (Jahan et al. 1994). Cytomixis involving transfer of chromatin material among proximate PMCs was observed during the first meiotic division at MI (Fig. 15) in the individuals studied from Gondhla. The transfer of chromatin material in these individuals resulted into chromosome stickiness and interbivalent connections in some PMCs. Besides, the cytomixis also resulted into considerable amount of pollen malformation (38-70\%) and heterogenous sized fertile pollen grains.

6. Potentilla fruticosa L.var. rigida (Wall. ex Lehm.) Th. Wolf Known as 'Shrubby Cinquefoil', was a small shrub with beautiful yellow flowers. It grow in dry valleys in high altitudinal regions. The species which reaches in full bloom during May-July was also grown for ornamental purposes. During meiosis, seven small sized bivalents were observed at MI (Fig. 16). Inter PMC transfer of chromatin was also observed through narrow cytoplasmic connections during the first and second meiotic division in some cases. Consequence to cytomixis, the plants studied from Marhi $(3,400 \mathrm{~m})$ region of Himalayas showed some pollen malformation (20\%). The species which was counted chromosomally for the first time from India added a new diploid cytotype $(2 n=14)$ to the already existing tetraploid cytotype $(2 n=28)$ from outside India (Ikeda 1989). It thus indicated that the species exhibited intraspecific polyploidy $(2 \mathrm{x}, 4 \mathrm{x})$.

7. Sedum ewersii Led. A glabrous perennial herb with dull whitish to pink colored flowers grew on moist stony slopes in Himalayas. Its flowers were used to treat goats in case of illness due to overtake of salts. During meiosis, 11 equal sized bivalents were regularly constituted at MI (Fig. 17) which showed regular segregation during anaphase I. Further meiotic course in these individuals was regular resulting into normal microsporogenesis and almost 100 percent pollen fertility. The present diploid chromosome count of $n=11$ was the first record from India but agrees with the earlier reports of $2 n=22$ from other parts of the world (Baldwin 1937, Uhl 1961,
Funamoto et al. 2007). An aneuploid cytotype with $2 n=20$ was already reported by Malik and Ahmad (1963) from Pakistan. It thus indicated that species depicts intraspecific aneuploidy at diploid level $(2 n=20,22)$.

8. Chrysanthemum pyrethroides (Kar. et Kir.) Fedtsch. It was an erect, woody, pubescent to woolly, aromatic herb with white ray florets and yellow disc florets which appear in June to August. The species grew frequently on alpine slopes and amongst boulders. Its flowers were constituents of incense. The plant was also used internally and externally for articular rheumatism and as poultice for boils. During the present investigations, two cytotypes i.e. the triploid $(2 n=27)$ and the tetraploid $(2 n=36)$ have been detected in the individuals collected form Batal 3,960 m (Spiti) area. However, these cytotypes could not be distinguished in the field on the basis of floral and vegetative characters.

A. Triploid The meiotic course in the individuals of triploid cytotype was highly abnormal due to the presence of large number of univalents besides bivalents at MI (Fig. 18). Analysis of several PMCs at diakinesis and MI revealed that the number of univalents in the different PMCs varied between 7-9 and that of bivalents from 9-10. Chromatin bridges were observed at telophase I. Microsporogenesis which was highly abnormal was characterized by the presence of monads $(2.31 \%)$, diads (61.85\%) (Fig. 20), diads with micronuclei (5.20\%), triads $(8.38 \%)$ (Fig. 22), triads with micronuclei $(01.24 \%)$ and tetrads with unequal sized units $(00.57 \%)$. Consequent to these meiotic abnormalities, pollen fertility was very low (26\%) and fertile pollen grains were of variable sizes.

B. Tetraploid The chromosome count of $n=18$ in this cytotype was confirmed from the presence of 18:18 chromosome distribution at AI (Fig. 19) and 36 chromosomes at mixed A1. Meiotic course in this cytotype was also highly abnormal. Late disjunction of many bivalents was clearly observed at AI. Restitution nuclei were formed at anaphase and some PMCs showed chromatin bridges. The microsporogenesis was also abnormal resulting into the formation of monads $(01.25 \%)$, dyads $(28.93 \%)$, dyads with micronuclei $(03.77 \%)$ (Fig. 21$)$, triads $(04.40 \%)$ and tetrads with micronuclei $(04.40 \%)$. The pollen fertility was low $(60 \%)$. The present chromosome counts of $2 n=27$ and $2 n=36$ were the first ever records for the species.

9. Waldhemia stoliczkai (Cl.) Osten.f. A beautiful creeping, ascending and tufted aromatic glabrous perennial herb which flower during June-August. It was a rare species in the moist alpine slopes. During meiosis, nine large sized bivalents were clearly observed at $\mathrm{MI}$ in PMCs (Fig. 23). The meiotic course in this diploid 
species was perfectly normal resulting into $100 \%$ pollen fertility. The present diploid chromosome count of $n=9$ was the first ever report for the species.

10. Waldhemia tomentosa (Decne) Regel It grow as a prostrate or ascending, white, grey, woolly, tufted and aromatic perennial herb. The species was a characteristic herb of dry alpine zones. It was an important constituent of incense along with $W$. glabra. The presently studied individuals revealed the existence of nine bivalents at MI and 9:9 chromosomes at two poles at AI (Fig. 24). Further meiotic course and microsporogenesis were normal resulting into $100 \%$ pollen fertility. This was the first ever chromosome count for the species.

Consequent to the present cytological studies from the cold desert region of Lahaul and Spiti which had not been covered earlier, three species Chrysanthemum pyrethroides $(2 \mathrm{n}=27,2 \mathrm{n}=36)$, Waldhemia stoliczkai $(\mathrm{n}=9)$ and $W$. tomentosa $(\mathrm{n}=9)$ have been counted chromosomally for the first time. Six species, Aquilegia fragrans $(\mathrm{n}=7)$, Astragalus bicuspis $(\mathrm{n}=8)$, Cicer microphyllum $(\mathrm{n}=8)$, Bergenia stracheyi $(\mathrm{n}=17)$, Sedum ewersii $(\mathrm{n}=11)$, Datisca cannabina $(\mathrm{n}=11)$ and Silene vulgaris $(\mathrm{n}=12)$ are worked out chromosomally for the first time from India. Additional/varied intraspecific aneuploid cytotype has been recorded in Hypericum elodeoides $(n=9)$ against the earlier report of $2 n=16$ from other parts of India and elsewhere. The phenomenon of cytomixis involving inter PMC migration of chromatin material has been recorded in Anemone rivularis $(\mathrm{n}=8)$, Caltha palustris $(\mathrm{n}=16)$, Meconopsis aculeata $(\mathrm{n}=28)$ and Potentilla fruticosa var. rigida $(\mathrm{n}=7)$. Cytomixis in Anemone rivularis $(\mathrm{n}=8)$ and Caltha palustris $(\mathrm{n}=16)$ resulted into pollen malformation and formation of heterogenous sized fertile pollen grains. Cytomixis in Caltha palustris and Meconopsis aculeata resulted into various meiotic irregularities like chromatin stickiness, pycnotic chromatin, micronuclei and laggards and bridges at telophases. In the remaining species the meiosis was perfectly normal leading to very high pollen fertility. Majority of the presently investigated species showed numerical chromosomal variations involving aneuploidy and/or polyploidy viz. Anemone rivularis (14, $16,24,28,48)$, Caltha palustris $(2 \mathrm{n}=16,28,32,35$, $38,40,42,44,48,50,52,54,55,57,56,58,60,64,68$, $72,88)$, Chrysanthemum pyrethroides $(2 \mathrm{n}=27,36)$, Hyoscyamus niger $(2 \mathrm{n}=34,36)$, Meconopsis aculeata $(2 \mathrm{n}=28,56)$, Nasturtium officinale $(2 \mathrm{n}=14,32,33,34,36$, 48, 60, 64), Phytolacca acinosa $(2 \mathrm{n}=18,36,72)$, Silene vulgaris $(2 \mathrm{n}=24,48)$, Hypericum elodeoides $(2 \mathrm{n}=16,18)$, Linum perenne $(2 \mathrm{n}=18,30,36)$, Potentilla fruticosa var. rigida $(2 \mathrm{n}=14,28)$, Spiraea sorbifolia $(2 \mathrm{n}=18,36)$ and Sedum ewersii $(2 \mathrm{n}=20,22)$.

ACKNOWLEDGEMENTS. The authors are grateful to the University Grants Commission, New Delhi for providing financial assistance under the DRS SAP I and II and ASIST programme. Thanks are also due to the Head, Department of Botany for necessary laboratory and library facilities.

\section{Literature Cited}

Baldwin, J. T. 1937. The cytotaxonomy of the Telephium section of Sedum. Amer. Journ. Bot. 24: 126-133.

Bhatia, H. S. 2005. Survey and Germplasm Evolution of Industrially Important High Altitude Drug Plant Species of North-West Himalaya. Ph.D. Thesis. Department of Botany, Punjabi University, Patiala.

Darlington, C. D. and Wylie A. P. 1955. Chromosome Atlas of Flowering Plants. George Allen. and Unwin Ltd. London.

Fedorov A. N. A. 1969. Chromosome Number of Flowering Plants. Academy of Science of the USSR Komarov Botancial Institute, Leningard (Reprint 1974).

Funamoto, T., Kondo, K., Tatarenko, I. V., Gontcharov, A., Smirnov, S. V. and De-yuan H. 2007. Somatic chromosome studies of six species of Hylotelephium (Crassulaceae) in Asian continent. Chrom. Bot. 2: 107-112.

Goldblatt, P. (ed.) 1981. Index to Plant Chromosome Numbers 1975-1978. Missouri Botan. Gard. 5, USA.

Goldblatt, P. (ed.), 1984. Index to Plant Chromosome Numbers 1979-1981. Missouri Botan. Gard., 8, USA.

Goldblatt, P. (ed.), 1985. Index to Plant Chromosome Numbers 1982-1983. Missouri Botan. Gard. 13, USA.

Goldblatt, P. (ed.), 1988. Index to Plant Chromosome Numbers 1984-1985. Missouri Botan. Gard. 23, USA.

Goldblatt, P. and Johnson, D. E. (eds.), 1990. Index to Plant Chromosome Numbers 1986-1987. Missouri Botan.Gard. 30, USA.

Goldblatt, P. and Johnson, D. E. (eds.), 1991. Index to Plant Chromosome Numbers 1988-1989. Missouri Botan.Gard. 40, USA.

Goldblatt, P and Johnson, D. E. (eds.), 1994. Index to Plant Chromosome Numbers 1990-1991. Missouri Botan.Gard. 51, USA.

Goldblatt, P. and Johnson, D. E. (eds), 1996. Index to Plant Chromosome Numbers 1992-1993. Missouri Botan.Gard. 58, USA.

Goldblatt, P. and Johnson, D. E. (eds.), 1998. Index to Plant Chromosome Numbers 1994-1995. Missouri Botan.Gard. 69, USA.

Goldblatt, P. and Johnson, D.E. (eds.), 2000. Index to Plant Chromosome Numbers 1996-1997. Missouri Botan.Gard. 81, USA.

Goldblatt, P. and Johnson, D. E. (eds.), 2003. Index to Plant Chromosome Numbers 1998-2000. Missouri Botan.Gard. 94, USA.

Goldblatt, P. and Johnson, D. E. (eds.), 2006. Index to Plant Chromosome Numbers 2001-2003. Missouri Botan. Gard. 106, USA.

Ikeda, H. 1989. Chromosome numbers of Himalayan Potentilla (Rosaceae). Jap. J. Bot. 64: 361-367.

Jahan, B. A. Vahidy, A. and Ali, S. I. 1994 Chromosome numbers in some taxa of Fabaceae mostly native to Pakistan. Ann. Missouri Bot. Gard 81: 792-799.

Jee, V., Dhar, U. and Kachroo, P. 1989. Cytogeography of some endemic taxa of Kashmir Himalaya. Proceedings of Indian National Science Academy Part B, Biological Sciences 55: 177-184.

Kumar, P. and Singhal V. K. 2008. Cytology of Caltha palustris L. (Ranunculaceae) from cold regions of Western Himalayas. Cytologia 73: 137-143.

Kumar, V. and Subramanian. 1986. Chromosome Atlas of Flowering Plants of the Indian Subcotinent Vol.I. Dicotyledons. BSI Calcutta.

Kurosawa, S. 1971. Cytological studies on some eastern Himalayan plants and their related species. In H. Hara (ed), Flora of Eastern Himalaya. Second Report, p. 335364. University of Tokyo Press. 
Löve, A and Löve, D. 1982. In Chromosome Number Reports LXXIV. Taxon 31:119-128.

Malik, N. A. and Ahmad, A. J. 1963. Chromosome numbers in some medicinal plants. Pak. J. Sci. Res.15: 58-60.

Malik, C. P. and Mary, T. N. 1970. Cytological studies in Caltha palustris Linn. var. normalis Hook. Beitr. Biol. Pflanz. 47: 63-70.

Mehra, P. N. and Remanandan, P. 1972. Cytology of some W. Himalayan Ranunculaceae. Cytologia 37: 281-296.

Moore, R. J. (ed.), 1973. Index to Plant Chromosome Numbers. 1967-1971. Reg. Veg. 90.

Moore R. J. (ed.), 1974. Index to Plant Chromosome Numbers. 1972. Reg. Veg. 91.

Moore R. J. (ed.), 1977. Index to Plant Chromosome Numbers. 1973-74. Reg.Veg. 96.

Pimenov, M. G., Tatyana, V., Alexeeva, E. V. and Kljuykov. 2006. IAPT/IOPB Chromosome Data 2 edited by Korf Marhold. Taxon 55: E1-E6.
Ratter, J. A. 1969. Cytological studies in Meconopsis. Notes Royal Botan. Gard. 28: 191-200.

Roy, S. C. and Sharma, A. K. 1971. Cytotaxonomic studies in Indian Ranunculaceae. Nucleus 14: 132-143.

Sandhu, P. S. and Mann, S. K. 1989. SOCGI Plant Chromosome Number Reports - VIII. J Cytol. Genet. 24: 179-183.

Singhal, V. K. and Kumar, P. 2008. Impact of cytomixis on the meiosis, pollen viability and pollen size in wild populations of Himalayan poppy (Meconopsis aculeata Royle). J. Biosci. 33: 371-380.

Sugiura, T. 1937. A list of chromosome numbers in angiospermous plants III. Botan. Mag. (Tokyo) 51: 425-426.

Sugiura, T. 1941. A list of chromosome numbers in angiospermous plants. I. Proc. Imper. Acad. (Tokyo) 17: 9-30.

Sugiura, T. 1944. Studies of the chromosome numbers in higher plants VI. Cytologia 13: 352-359.

Uhl, C. H. 1961. The chromosomes of Sempervioideae (Crassulaceae). Amer. Journ. Bot. 48:114-123. 